\title{
Measuring the Impact of Fortified Milk on Children's Health in Pakistan
}

\author{
Afsheen Aslam, ${ }^{1}$ Zahoor Hussain Javed, ${ }^{2}$ Samra Suhabani, ${ }^{3}$ Ghulam Jilani, ${ }^{4}$ Muhammad Ikhlaq Anwar, ${ }^{5}$ Muhammad Akhtar Pervaiz 6 \\ 1,2,3Department of Economics, Govt. College University, Faisalabad-Pakistan, ${ }^{4}$ Department of Economics, University of Agriculture, Faisalabad-Pakistan, ${ }^{5}$ Department of Biochemistry, \\ Faisalabad Medical University, Faisalabad-Pakistan, ${ }^{6}$ Department of Community Medicine, The University of Faisalabad, Faisalabad-Pakistan.
}

\section{ABSTRACT}

Background: The recommended intake of fortified milk can substantially decrease the children's ailment, increase growth rate and appears an economically beneficial strategy in the general Pakistani population aged over 6-24 months. Objective: The aim of this study is to determine the influence of fortified milk on children's health in Pakistan. Study Design: Randomized controlled trial. Settings: Department of Economics, GC University, Faisalabad-Pakistan. Duration: April 2019 to August 2019. Sample Size: Consisted of 100 individuals. Sampling Technique: Snowball technique was used to collect data. Data Analysis: Pretest and posttest data were analyzed with the help of t-test, paired sample t-test, and crosstabulation. Results: It was found that there was a significant difference between the mean difference in age, height ratio of participants from their pretest and post-test scores. Conclusion: Fortified milk brings positive changes in growth of children in terms of weight \& height.

Suggestions: The mass should have awareness regarding fortified complementary foods.

Keywords: Fortified milk, Children, Faisalabad, Pakistan.

Corresponding Author

Submitted for Publication: 01-12-2019

Accepted for Publication: 07-04-2020

Zahoor Hussain Javed, Assistant Professor, Department of Economics, Govt. College University, Faisalabad-Pakistan.

Email: javedmarth02@gmail.com

Citation: Aslam A, Javed ZH, Suhabani S, Jilani G, Anwar MI, Pervaiz MA. Measuring the Impact of Fortified Milk on Children's Health in Pakistan. APMC 2020;14(2):106-11.

\section{DOI: $10.29054 / A P M C / 2020.789$}

\section{INTRODUCTION}

Good health is the right of every human being. Today's healthy child is the treasure of future as it has the ability to become the backbone of society in the process of development. Developing countries residing on the agricultural goods feed their children with natural milk. This milk is not rich in all nutrients that are required by the children. To fill this gap of nutrients the developed countries has discovered the formula of fortified milk that is enriched with all sufficient nutrients of balanced diet. In developing countries, another reason to use fortified milk that is the unavailability of pure milk. The current study examined the effect of fortified milk compared with animal's milk on the growth, height, weight and nutritious status of young children in Pakistan. Fortified milk is manufactured milk that consists on additional mineral and vitamins which are not found in natural milk in sufficient quantity. Usually, vitamins $A$ and $D$ are supplemented to milk, however it can be fortified with various other nutrients like iron, folic acid, phosphors, calcium, Riboflavin, fat and protein.

In low-income countries, the consumption of fortified milk and other animal-source foods is very limited. In many African countries, Sub-Saharan Africa, Southern Asia, Eastern, Mexico, Northern Asia, Southern Asia, Canada, Europe, Australia, and United States, animal-source foods provide less than $5 \%$ of total energy, $5 \%$ to $10 \%, 10 \%$ to $15 \%$ and more than $20 \%$ respectively. ${ }^{1}$ In the developing countries, a significant part (30$50 \%$ ) of children face issues of underweight, acute respiratory infections, diarrheal disease, ailment, or inhibited growth, because of low per capita income ${ }^{2}$. In developing countries like Pakistan face issues of micronutrient insufficiencies and protein- energy malnourishment among children are still a huge health concern. Malnourishment is main cause of diminished growth and cognitive development. ${ }^{3}$ The youngest age is the part of life when children grow rapidly, both physically and mentally. With the increasing age of young children, they need high amount of nutrition for their development and growth. In the early 6-24 months of life, the young children get breast-feeding, which is indisputable; nevertheless, after weeping of a baby, during the dietary transition period, dietary intake cannot be continuously optimal. ${ }^{4}$ Since, young children cannot take solid food at the age of 2 years, a lack of access to appropriate nutritious leads to suboptimal dietary intake, and this suboptimal intake may be created due to food neophobia and 'fussy' eating attitude. ${ }^{5}$ Investigators have investigated those children who eat neophobia food, they have limited dietary variety. ${ }^{6,7}$ Animal's milk is commonly consumed and this food has been accepted among group of young children. ${ }^{8}$ The components of animal's milk are bases of protein, $\mathrm{Ca}$ and fat. Nonetheless, these micronutrients are not sufficient for development and growth for young children. Moreover, $\mathrm{Fe}$ is the most common deficient micronutrient in the world. ${ }^{9}$ The deficiency of other nutrients like vitamin $D^{10}$ and $n-3$ essential fatty acids negatively influence children's growth. ${ }^{11}$ Thus, fortified milk may be replaced with a poor source of key nutrients of animal's milk. So, optimal nutritional intake among young children can be achieved from appropriate nutritious foods. The WHO recommends using fortified milk when children do not achieve suitable nutrient intake from their diet. ${ }^{12}$ 
Milk fortification is an efficient source of supplementary nutrition for children if used in a suitable amount along with a normal diet. $^{13-16}$

Milk gives an adequate and efficient means for delivery of definite micronutrients, especially zinc and iron. Furthermore, the WHO rules on improving newborn child and small kid wellbeing and suggest the use of refreshed nourishments when youngsters are not getting adequate supplement consumption from their eating routine in Pakistan. ${ }^{17,18}$

The education of parents plays a vital role in the health of a child. ${ }^{19}$ Education and nutrition increased dietary quality among children. Maternal education can also influence healthy decision making, which in turn affects the growth of a child. ${ }^{20,21}$ Researches in developing countries have shown that children of literate mothers have a lower risk of stunting. ${ }^{22,23}$ It is well recognized that the period between birth and two years is most important time for the prevention of malnutrition. After the age of two years, it is very difficult to reverse the effects of stunting. ${ }^{24}$ In industrialized countries, fortified baby formulations are commonly used with substantial amount of iron in their supplements. Manufactured complementary foods are well accepted in both rich and limited resources societies and are consumed by large proportions of the population, even those within the lowest income bracket. 25 Fortifications of cerealbased foods reduce the prevalence of anemia and improve the zinc and iron status of infants and toddlers. In Pakistan, a lowcost fortified cereal-based food has significantly improved development of infants. ${ }^{26}$ Whereas in India the consumption of fortified dried milk powder has significantly increased linear growth. Hence the use of fortified complementary foods enhances the nutrient adequacy of the diets of infants and toddlers for growth and immune function. Category two contains fortificants that are poorly soluble in water but readily dissolve in dilute acid and hence are soluble in the gastric juices of the duodenum. Ferrous fumarate, the most commonly used of the category two fortificants, has an RBV of 100 in adults but has recently been shown to have an RBV of only $30-35$ in preschool children. ${ }^{25}$

The WHO advocates the use of category three fortificants as a last resort, and if used, only those with an RBV of at least $50 \%$ should be selected (WHO/FAO 2006). ${ }^{28}$ Fortificants in categories one to three are all subject to the same factors that enhance and inhibit the absorption of native non-haem iron.

The final category of fortificants contains the iron chelates or 'protected' iron fortificants, namely NaFeEDTA and ferrous bisglycinate, characterized by their high bioavailability even in the presence of inhibitors. Recently Indonesian school children subsequently, strengthened milk-based supplementation for preschool kids' eating regimens improved in general nourishing status, supplement admission, and execution on the psychomotor scale. It is considered very important for the benefit and welfare of the masses. The researchers found limited studies in Pakistan on the effect of fortified milk on children's health. Consequently, more studies are needed in this field. Therefore, study has been conducted and will play a vital role in improving children's health.
METHODOLOGY

Study Design: Randomized controlled trail of 4 months duration conducted in young children.

Settings: Department of Economics, G C University

Faisalabad, Pakistan.

Intervention: Fortified milk

Control Intervention: Animal's milk

Eligibility Criteria:

The criteria of research had following features:

(i) Healthy children aged 6-12 months; (ii) fortified milk; (iii) control was animal's milk or; (iv) growth, height and weight parameters.

Duration: From April 2019 to August 2019.

Inclusion criteria: Healthy children range 6-24 months were included in this study.

Exclusion criteria: Incongruity and unhealthy children are excluded from the study.

Sample Technique: The present study carried out over 4 months from April 2019 to August 2019. It included 100 children aged 6-24 months to determine the effect of fortified milk on children's health from the Faisalabad city including Gulberg, Police lines, civil lines, railways colony, Kachi Abadi, Nazimabad, Sheikh Colony and Liaqat Abad. For this purpose, the investigators developed a chart for children which are based on three variables of investigation such as age, height, and weight in combination together. This research project has been approved by the ethics committee; board of studies, advanced study research board (ASRB) and academic council of Government College University, Faisalabad, Pakistan. The young children have been taken from Gulberg, Police lines, civil lines, railways colony, Kachi Abadi, Nazimabad, Sheikh Colony and Liaqat Abad for this study. These young children have been divided into two groups. Fortified milk was given to a group, while animal's milk was given to another group with consent of their mother. The parents of each child were informed procedure and objective of this project before participation in the study. This study is based on double-blind. The data was collected through the snowball technique. Data were divided into two equal groups such as Control and Experimental groups. Experimental group was given $250 \mathrm{ml}$ fortified milk under the supervision of their mother for four months, while Control group was given $250 \mathrm{ml}$ animal's milk for same period. Pre-test data from Control and Experimental groups were collected which was based on their age*height and age*weight ratios. The later intervention was applied to the children of the Experimental and control groups for the period not exceeding four months. Animal's milk was taken from Milkmen or hotels, while fortified milk was taken from medical stores of Faisalabad. After the period of four months, post-test data were collected from control and experimental groups, so data may be analyzed accordingly. Sample Size: Consisted of 100 individuals.

\section{RESULTS}

Pretest and post test data were analyzed with the help of descriptive statistics, t-test, paired sample t-test, and cross- 
tabulation by using Statistical Package for Social Sciences (SPSS).

The researcher was able to determine effect of fortified milk on the anemic condition of the children. In this regard, the following table was used to compare if any change occurred in favor of height to weight growth of anemic children at the end of the study.

The findings about average/normal height of Boys and Girls with respect to their age groups are reported in Table 1.

Table 1: Average/normal height of boys and girls with respect to their age groups

\begin{tabular}{|c|c|c|c|c|}
\hline & Male & Female & Male & Female \\
\hline $\begin{array}{c}\text { Age } \\
\text { (Months) }\end{array}$ & $\begin{array}{c}\text { Height } \\
\text { (cm) } \\
\pm 10 \% \\
\end{array}$ & $\begin{array}{c}\text { Height } \\
(\mathrm{cm}) \\
\pm 10 \%\end{array}$ & $\begin{array}{c}\text { Weight } \\
\text { (kg) } \\
\pm 10 \% \\
\end{array}$ & $\begin{array}{c}\text { Weight } \\
(\mathrm{kg}) \\
\pm 10 \%\end{array}$ \\
\hline 6 & 63.6 & 61.5 & 6.4 & 5.8 \\
\hline 7 & 65.1 & 62.9 & 6.7 & 6.1 \\
\hline 8 & 66.5 & 64.3 & 7 & 6.3 \\
\hline 9 & 67.7 & 65.6 & 7.2 & 6.6 \\
\hline 10 & 69 & 66.8 & 7.5 & 6.8 \\
\hline 11 & 70.2 & 68 & 7.4 & 7 \\
\hline 12 & 71.3 & 69.2 & 7.8 & 7.1 \\
\hline 13 & 72.4 & 70.3 & 8 & 7.3 \\
\hline 14 & 73.4 & 71.3 & 8.2 & 7.5 \\
\hline 15 & 74.4 & 72.4 & 8.4 & 7.7 \\
\hline 16 & 75.4 & 73.3 & 8.5 & 7.8 \\
\hline 17 & 76.3 & 74.3 & 8.7 & 8 \\
\hline 18 & 77.2 & 75.2 & 8.9 & 8.2 \\
\hline 19 & 78.1 & 76.2 & 9 & 8.3 \\
\hline 20 & 78.9 & 77 & 9.2 & 8.5 \\
\hline 21 & 79.7 & 77.9 & 9.3 & 8.7 \\
\hline 22 & 80.5 & 78.7 & 9.5 & 8.8 \\
\hline 23 & 81.3 & 79.6 & 9.7 & 9 \\
\hline 24 & 82.1 & 80.3 & 9.8 & 9.2 \\
\hline
\end{tabular}

Source: WHO child growth standards

Intervention Applied: Anemic children of the experimental group were given treatment based on usage of fortified milk enriched with Zinc $(1.19 \mathrm{mg})$ and $\mathrm{Fe}(3.28 \mathrm{mg})$ as compared to unfortified milk for a period of 4 months. Anemic Children of Control group were prescribed by physicians to let them usage unfortified milk of cow regularly so later results of both groups may be compared accordingly.

Validity and reliability of the research tool: The validity of the instrument was validated with the help of consultant doctors especially children specialists having experience not less than 10 years. Later pilot testing was done to access the feasibility of the study and to access the reliability of the study. Cronbach Alpha was 0.92 which was considered to be good to proceed for main study.

The nutritional value of fortified and unfortified milk is given in Table 2. They are comprised on of energy, fat, zinc, phosphate, calcium, sodium, carbohydrate, vitamin $A$, vitamin $D$, vitamin $E$, vitamin $\mathrm{K}$, vitamin $\mathrm{C}, \mathrm{B}_{1}, \mathrm{~B}_{2}, \mathrm{~B}_{3}, \mathrm{~B}_{6}, \mathrm{M}_{9}$, $\mathrm{Fe}$ and Zinc etc.

Table 2: Composition of fortified and animal's Milk

\begin{tabular}{|l|c|c|}
\hline \multicolumn{1}{|c|}{$\begin{array}{c}\text { Nutrition value } \\
\text { Preserving }\end{array}$} & $\begin{array}{c}\mathbf{2 7} \mathbf{g} \\
\text { Fortified Milk } \\
\text { (A) }\end{array}$ & $\begin{array}{c}\mathbf{2 7} \mathbf{g} \\
\text { Animal's Milk } \\
\text { (B) }\end{array}$ \\
\hline Energy (Kcal) & 100 & 100 \\
\hline Fat (g) & 3.7 & 3.2 \\
\hline Protein (g) & 4 & 3.5 \\
\hline Carbohydrate (g) & 12.7 & 9.9 \\
\hline Phosphate (mg) & 250 & 231 \\
\hline Sodium (mg) & 59 & 53 \\
\hline Vitamin A (lu) & 396 & 319 \\
\hline Vitamin D 3 (lu) & 51 & 51 \\
\hline Vitamin E (lu) & 5 & 3 \\
\hline Vitamin K (mcg) & 9.1 & 7.1 \\
\hline Vitamin C (mg) & 50 & 35 \\
\hline B1 (mg) & 0.09 & 0.07 \\
\hline B2 (mg) & .31 & .27 \\
\hline B3 (mg) & 1.43 & 1.1 \\
\hline B6 (mg) & 0.14 & 0.9 \\
\hline M9 (mg) & 44 & 41 \\
\hline M12 (mcg) & 1.4 & 0.3 \\
\hline Potassium (mg) & 194 & 185 \\
\hline Magnesium (mg) & 179 & 13 \\
\hline Zinc (mg) & & .23 \\
\hline Fe (mg) & 114 \\
\hline Ca (mg) & & \\
\hline Phosphors (mg) & & 173 \\
\hline
\end{tabular}

Table 3: Age wise classification of children

\begin{tabular}{|c|c|c|}
\hline Age (months) & Frequency & Percentage \\
\hline $\mathbf{6 - 1 2}$ & 59 & $59 \%$ \\
\hline $13-24$ & 41 & $41 \%$ \\
\hline Total & 100 & $100 \%$ \\
\hline
\end{tabular}


Table 3 represents an age-wise classification of children participated in this study. It was found that there was a total of 100 children participated in this study; those were having age between six months to two years (24 months) maximum. $59 \%$ children have age between 6 to 12 months of age, while $41 \%$ children were having age between 13 to 24 months.

Table 4: Classification with respect to parent's qualification

\begin{tabular}{|c|c|c|}
\hline Qualification & Frequency & Percentage \\
\hline Below MA & 42 & $42 \%$ \\
\hline MA & 44 & $44 \%$ \\
\hline Above MA & 14 & $14 \%$ \\
\hline Total & 100 & $100 \%$ \\
\hline
\end{tabular}

The above table highlights the qualification level of children's parents of children who participated in this in both groups such as control and experimental. Results show that most of the parents were well educated and they were holding a Master's degree or higher.

Table 5: Classification with respect to Income status of parents

\begin{tabular}{|c|c|c|}
\hline Qualification & Frequency & Percentage \\
\hline Below $\mathbf{3 0}$ & 19 & $19 \%$ \\
\hline $\mathbf{3 0 - 4 0}$ & 55 & $55 \%$ \\
\hline Above $\mathbf{4 0}$ & 26 & $26 \%$ \\
\hline Total & 100 & $100 \%$ \\
\hline
\end{tabular}

Table 5 indicates the classification of respondents with respect to the income status of parents of children. The table shows that the income of parents of 19 participants was below 30 thousand, the income of parents of 55 students was in the range of 30-40 thousand, and the income of parents of 26 participants was above 40 thousand rupees.

Table 6: Age to weight ratio (Pre-test)

\begin{tabular}{|c|c|c|c|c|c|c|}
\hline Groups & N & Mean & SD & Df & t-value & Sig \\
\hline Control & 50 & 90.74 & 33.39 & \multirow{2}{*}{98} & .612 & $.542^{* *}$ \\
\hline Experimental & 50 & 86.78 & 31.18 & & & \\
\hline
\end{tabular}

${ }^{* *} p<0.05$ (Significant)

The analyzed results of the independent sample t-test presented in the above-said table show that there was no significant difference exists in favor of age ${ }^{*}$ weight ratio of children who participated in both control( $M=90.74, S D=33.39)$ and experimental $(M=86.78, S D=31.18)$ groups were $t(98)=$ 0.612 . The calculated value of $p$ is also greater than the assumed significance level (0.05).
These results presented that the age ${ }^{*}$ weight ratio of participants included in both groups was homogenous with no significant difference.

Table 7: Age to height ratio (pre-test)

\begin{tabular}{|c|c|c|c|c|c|c|}
\hline Groups & $\mathbf{N}$ & Mean & SD & Df & t-value & Sig \\
\hline Control & 50 & 806.99 & 275.19 & \multirow{2}{*}{98} & \multirow{2}{*}{.658} & \multirow{2}{*}{$.512^{* *}$} \\
\hline Experimental & 50 & 772.10 & 254.99 & & & \\
\hline
\end{tabular}

${ }^{* *} p<0.05$ (Significant)

The analyzed results of the independent sample t-test presented in the above-said table show that there was no significant difference exists in favor of the age*height ratio of children who participated in both control( $M=806.99, S D=275.19)$ and experimental $(M=772.10, S D=254.99)$ groups were $t(98)=$ 0.658 . The calculated value of $p$ is also greater than the assumed significance level $(0.05)$. These results presented that the age*height ratio of participants who participated in both groups was homogenous with no significant difference.

Table 8: Age to weight ratio (Post-test)

\begin{tabular}{|c|c|c|c|c|c|c|}
\hline Groups & N & Mean & SD & Df & t-value & Sig \\
\hline Control & 50 & 123.10 & 40.81 & \multirow{2}{*}{98} & -2.32 & $.022^{*}$ \\
\hline Experimental & 50 & 142.27 & 41.77 & & & \\
\hline
\end{tabular}

${ }^{*} p<0.05$ (Significant)

The analyzed results of the independent sample t-test presented in above said table show that there was a significant difference exists in favor of the age ${ }^{*}$ weight ratio of children who participated in both control $(M=123.10, S D=40.81)$ and experimental $(M=142.27, S D=41.77)$ groups were $t(98)=-2.32$. The calculated value of $p$ is also less than the assumed significance level $(0.05)$. These results clearly show positive change observed in favor of an appropriate increase in the weight of children who participated in experimental groups as compared to children who were part of the control group. This is also evidence that the aforementioned change occurred as a result of the regular usage of fortified milk recommended to the children of the experimental group.

\section{DISCUSSION}

The current study examined the effect of fortified milk compared with control milk on the growth, height, weight and nutritious status of young children. However, the encompassed studies demonstrated significant statistical heterogeneity. ${ }^{11}$ The study identified growth trends in relevant parameters and biochemical markers among children in the intervention group. ${ }^{27}$ There was a significant effect of fortified milk on height and weight gain among children in the interference groups equated with control group. The empirical evidence suggesting fortified milk positively affect growth and others relevant parameters among young children than control group. ${ }^{17-19}$ Empirical evidence of 
further studies emphasizes that fortified milk promote growth and weight gain of young group of children. ${ }^{14}$ Milk fortification is portion of a public health intervention program in developing countries. In this regard two articles have been reviewed. The present review of studies in Asian countries identified that fortified milk has normal growth potential in young children. Additionally, the study effect of fortified milk on young children in India emphasizes that fortified milk deeply effects the growth and height of children. The effect of fortified milk with dietary supplement investigated in two others Asian studies ${ }^{26}$ which emphasize that dietary supplements support immune function with promoting normal growth in young children. The current meta-analysis and systematic empirical evidence recognized that use of fortified milk develop aspects of nutritious status, mainly $\mathrm{Fe}$, in young children. ${ }^{29}$

Our results clearly show positive change observed in favour of an appropriate increase in the weight of children who participated in experimental groups as compared to children who were part of the control group. This is also evidence that the aforementioned change occurred as a result of the regular usage of fortified milk recommended to anaemic children of the experimental group. ${ }^{12}$ The outcomes of the above study show treatments are given which are based on usage of fortified milk to anemic children of the experimental group really helped them to get recover normal weight, height, growth which may be considered better than those children who do not use fortified milk. Hence the null hypothesis is rejected. Our study findings coincide with findings of research conducted in other developed and developing countries. ${ }^{7}$

\section{CONCLUSION}

In the current study, the outcomes show positive change observed in favor of an appropriate increase in weight, the height of children participated in experimental groups as compared to the control group. Thus, fortified milk has a very strong potential for improving quality of life of young children in Pakistan.

\section{SUGGESTIONS / RECOMMENDATIONS}

The use of fortified complementary foods can divert caregivers away from providing their children with other nutrient-dense traditional foods. Therefore, efforts to raise public awareness for the importance and use of fortified milk are essential. Further, it is also suggested that the Government should take steps to avail the fortified milk free of cost or subsidize it to make it accessible to the poor people.

\section{CONFLICT OF INTEREST / DISCLOSURE}

There is no conflict of interest in to be declared.

\section{ACKNOWLEDGEMENTS}

We acknowledge the academic help consultant of Faisalabad Medical University and Allied Hospital Faisalabad.

\section{REFERENCES}

1. Keskin Y, Moschonis G, Dimitriou M, Sur H, Kocaoglu B, Hayran $O$, Manios $Y$. Prevalence of iron deficiency among schoolchildren of different socio-economic status in urban Turkey. Eur $\mathrm{J}$ Clin Nutr. 2005;59(1):64-71.

2. Van Nhien N, Khan NC, Ninh NX, Van Huan P, Hop le T, Lam NT Ota $F$, et al. Micronutrient deficiencies and anemia among preschool children in rural Vietnam. Asia Pac J Clin Nutr. 2008;17(1):48-55.

3. Semba RD, Moench-Pfanner R, Sun K, De Pee S, Akhter N, Rah $\mathrm{JH}$, Campbell AA, Badham J, Bloem MW, Kraemer K. Consumption of micronutrient-fortified milk and noodles are associated with a lower risk of stunting in preschool-aged children in Indonesia. Food Nut Bult. 2011;32(4):347-53.

4. Eichler K, Wieser S, Rüthemann I, Brügger U. Effects of micronutrient fortified milk and cereal food for infants and children: a systematic review. BMC Pub Heal. 2012;12(1):506-9.

5. Petrova D, Litrán MA, García-Mármol E, Rodríguez-Rodríguez M, Cueto-Martín B, López-Huertas E, Catena A, Fonollá J. Effects of fortified milk on cognitive abilities in school-aged children: results from a randomized-controlled trial. Eur J Nutr. 2019;58(5):186372.

6. Detzel $\mathrm{P}$, Wieser $\mathrm{S}$. Food fortification for addressing an iron deficiency in Filipino children: benefits and cost-effectiveness. Ann Nutr Metab. 2015;66(2):35-42.

7. Sazawal S, Dhingra U, Dhingra P, Hiremath G, Kumar J, Sarkar A, Menon VP, Black RE. Effects of fortified milk on morbidity in young children in north India: a community-based, randomized, double-masked placebo-controlled trial. BMJ. 2007;334(7585):140.

8. RM, Badcock JC, Giay T, Ngu T, Waters AM, Bennett SA. Effect of nutrition improvement project on morbidity from infectious diseases in preschool children in Vietnam: comparison with control commune. BMJ. 1997;315(7116):1122-5.

9. Matsuyama M, Harb T, David M, Davies PS, Hill RJ. Effect of fortified milk on growth and nutritional status in young children: a systematic review and meta-analysis. Public Health Nutr. 2017;20(7):1214-25.

10. Van Stuijvenberg ME, Kvalsvig JD, Faber M, Kruger M, Kenoyer DG, Benadé AJ. Effect of iron-, iodine-, and betacarotene-fortified biscuits on the micronutrient status of primary school children: a randomized controlled trial. Am J Clin Nutr. 1999;69(3):497-503.

11. Dunn JT, Crutchfield HE, Gutekunst R, Dunn AD. Two simple methods for measuring iodine in urine. Thyroid. Summer 1993;3(2):119-23.

12. International Clinical Epidemiology Network. http://www.inclentrust.org

13. Allen $L$, de Benoist B. Dary $O$. Guidelines on food fortification with micronutritients. Edited by WHO Food and Agricultural Organization of the United Nations. Geneva, Hurrel R; 2006.

14. Graham D, Kira G, Conaglen J, McLennan S, Rush E. Vitamin D status of Year 3 children and supplementation through schools with fortified milk. Public Health Nutr. 2009;12(12):2329-34.

15. Anekwe, TD \& Kumar $\mathrm{S}$. The effect of a vaccination program on child anthropometry: Evidence from India's universal immunization program. J Public Health. 2012;34(4):489-97.

16. Allen LH. Anemia and iron deficiency: effects on pregnancy outcome. Am J Clin Nutr. 2000;71(5):1280-4.

17. Benjeddou K, Qandoussi L, Mekkaoui B, Rabi B, El Hamdouchi A, Raji F, Saeid N, Belghiti H, Elkari K, Aguenaou H. Effect of multiple micronutrient fortified milk consumption on vitamin $D$ 
status among school-aged children in rural region of Morocco. Appl Physiol Nutr Metab. 2019;44(5):461-7.

18. Cervo MM, Mendoza DS, Barrios EB, Panlasigui LN. Effects of Nutrient-Fortified Milk-Based Formula on the Nutritional Status and Psychomotor Skills of Preschool Children. J of Nutr Metab. 2017;2017.6456738.

19. Sidnell, A, Pigat, S, Gibson, S etal. (2016). Nutrient intakes and iron and vitamin $D$ status differ depending on main milk consumed by UK children aged 12-18 months - secondary analysis from the Diet and Nutrition Survey of Infants and Young Children. J Nutr Sci. 2016;5:e32.

20. Moher D, Liberati A, Tetzlaff J, Altman DG. Preferred reporting items for systematic reviews and meta-analyses: the PRISMA statement. Ann Intern Med. 2009;151(4):264-269.

21. Heird WC. Progress in promoting breast-feeding, combating malnutrition, and composition and use of infant formula, 19812006. J Nutr. 2007;137(2):499-502.

22. Allen LH, Peerson JM, Olney DK. Provision of multiple rather than two or fewer micronutrients more effectively improves growth and other outcomes in micronutrient-deficient children and adults. J Nutr. 2009;139(5):1022-30.

23. Maldonado Lozano J, Baro L, Ramirez-Tortosa MC, Gil F, Linde J, Lopez-Huertas E, Boza JJ, Gil A. Intake of an ironsupplemented milk formula as a preventive measure to avoid low iron status in 1-3-year-olds. An Pediatr (Barc). 2007;66(6):59.

24. Morley R, Abbott R, Fairweather-Tait S, MacFadyen U, Stephenson T, Lucas A. Iron fortified follow on formula from 9 to 18 months improves iron status but not development or growth: a randomised trial. Arch Dis Child. 1999;81(3):247-52.

25. Maldonado Lozano J, Baro L, Ramirez-Tortosa MC, Gil F, Linde J, Lopez-Huertas E, Boza JJ, Gil A. Intake of an ironsupplemented milk formula as a preventive measure to avoid low iron status in 1-3-year-olds. An Pediatr (Barc). 2007;66(6):591-6.

26. Firmansyah, A, Dwipoerwantoro, $P G$, Kadim, $M$ et al. Improved growth of toddlers fed a milk containing synbiotics. Asia Pac J Clin Nutr. 2011;20(1):69-76.

27. Brisbois TD, Farmer AP \& McCargar LJ. Early markers of adult obesity: a review. Obes Rev. 2012;13(4):347-67.

28. Conclusions and recommendations of the WHO consultation on prevention and control of iron deficiency in infants and young children in malaria-endemic areas. Food and Nutrition Bulletin. 2007;28(4):621-63.

29. Virtanen, M, Svahn, C, Viinikka, L et al. (2001) Iron-fortified and unfortified cow's milk: effects on iron intakes and iron status in young children. Acta Paediatr. 2001;90(7):724-31.

$\begin{array}{ll}\text { AUTHORSHIP CONTRIBUTION } \\ \text { Afsheen Aslam } & \text { Data Collection, Writeup } \\ \text { Zahoor Hussain Javed } & \text { Data Analysis } \\ \text { Samra Suhabani } & \text { Compiled the Paper } \\ \text { Ghulam Jilani } & \text { Literature Review } \\ \text { Muhammad lkhlaq Anwar } & \text { Results Compiling } \\ \text { Muhammad Akhtar Parvaiz } & \text { Proof Reading, Final Layout }\end{array}$

